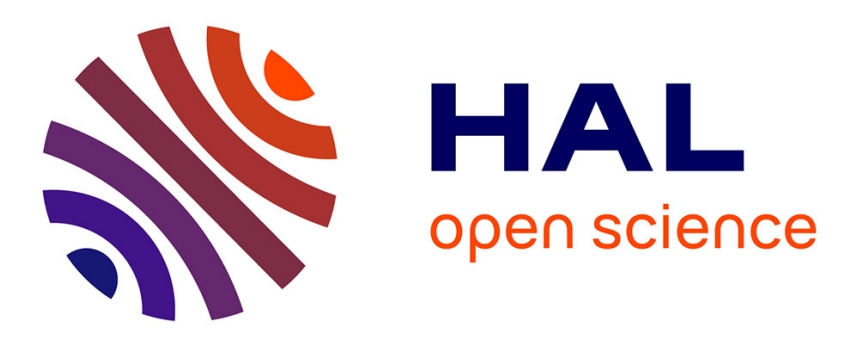

\title{
Oxygen Isotope Records and Salinity Changes in the Northeastern Atlantic Ocean during the Last 18,000 Years
}

\author{
J.C. Duplessy, Edouard Bard, L. Labeyrie, J. Duprat, J. Moyes
}

\section{- To cite this version:}

J.C. Duplessy, Edouard Bard, L. Labeyrie, J. Duprat, J. Moyes. Oxygen Isotope Records and Salinity Changes in the Northeastern Atlantic Ocean during the Last 18,000 Years. Paleoceanography, 1993, 8 (3), pp.341-350. 10.1029/93PA00455 . hal-03584481

\author{
HAL Id: hal-03584481 \\ https://hal.science/hal-03584481
}

Submitted on 22 Feb 2022

HAL is a multi-disciplinary open access archive for the deposit and dissemination of scientific research documents, whether they are published or not. The documents may come from teaching and research institutions in France or abroad, or from public or private research centers.
L'archive ouverte pluridisciplinaire HAL, est destinée au dépôt et à la diffusion de documents scientifiques de niveau recherche, publiés ou non, émanant des établissements d'enseignement et de recherche français ou étrangers, des laboratoires publics ou privés. 
PALEOCEANOGRAPHY, VOL. 8, NO. 3, PAGES 341-350, JUNE 1993

\section{OXYGEN ISOTOPE RECORDS AND SALINITY CHANGES IN THE NORTHEASTERN ATLANTIC OCEAN DURING THE LAST 18,000 YEARS}

\author{
J. C. Duplessy, ${ }^{1}$ E. Bard, ${ }^{1,2}$ L. Labeyrie, ${ }^{1}$ \\ J. Duprat, ${ }^{3}$ and J. Moyes ${ }^{3}$
}

Abstract. A comparison of the deglaciation $\delta^{18} \mathrm{O}$ record of northeastern Atlantic core SU 81-18 with that calculated by adding the $\delta^{18} O$ changes due to sea surface temperature and ice volume variations shows that planktonic foraminifera have also recorded seawater $\delta^{18} \mathrm{O}$ changes due to salinity (local advection and evaporation-precipitation (E-P)) changes. Using a simple ocean box model of meltwater dilution during the deglaciation, we show that sea surface salinity covaried with temperature. Despite the injection of meltwater associated with the climate warming, sea surface salinity was high when sea surface water was warm and low during cold events. This implies that the combined effect of local E-P changes and northward advection of saline subtropical water were the main factor responsible for the surface water salinity variations in the northeastern Atlantic Ocean during the last 18,000 years.

\section{INTRODUCTION}

Pleistocene glacial-interglacial oscillations resulted in large variations of surface water temperature, continental ice volume, and sea level [Emiliani, 1955; CLIMAP Project Members, 1976; 1981; Fairbanks, 1989]. According to a theory developed by Milankovitch [1930], insolation changes due to variations of the position of the Earth on its orbit around the Sun trigger

\footnotetext{
'Centre des Faibles Radioactivites, Laboratoire mixte Centre National d'Etudes Spatiales - Commissiariat à l'Energie Atomique, Gif sur Yvette, France.

${ }^{2}$ Now at Laboratorie des Geosciences de l'Environnement, Univèrsite d' Aix-Marseille III, Facultè de St Jèrôme. Marseille, France.

${ }^{3}$ Laboratoire de Gèologie et Ocèanographie, Universitè de Bordeaux, Talence, France.
}

Copyright 1993

by the American Geophysical Union.

Paper number 93PA00455. 0883-8305/93/93PA-00455\$10.00 these long-term climatic variations. This theory is widely accepted in its generalized form [Hays et al., 1976; Imbrie and Imbrie, 1980; Imbrie et al., 1984, 1989]. However, detailed climatic records obtained by pollen changes in peat bogs and lake sediment, isotopic analyses of long ice cores and by micropaleontologic and isotopic study of deep-sea sediments reveal abrupt changes, which are too rapid to be explained by a linear response of the climatic system to the more slowly varying astronomical insolation changes. Broecker and Denton [1989] suggested that these rapid climatic fluctuations [Mangerud, 1970; Woillard, 1978; Hammer et al., 1985] can only be explained by changes in temperature, evaporation, precipitation, and salinity at the surface of the North Atlantic, which would result in changes in ocean circulation and heat transport to the high latitudes. The rationale behind this theory is that, under present conditions, the North Atlantic Drift carries a large amount of heat which is released in high latitude areas and maintains over Europe a climate much milder than that prevailing over eastern North America. If this heat transport were to cease, a considerable cooling of the whole North Atlantic Ocean and nearby continents would be expected, possibly leading to glacial conditions in the northern hemisphere.

A change in the rate of deepwater formation can cause considerable warming or cooling at least at the scale of the North Atlantic basin [Watts, 1985; Berger, 1990; Broecker and Denton, 1989]. Salt is inferred to play a major role in this process, because Atlantic circulation is sensitive to surface salinity. Sinking of surface water can slow down or even stop if the surface water density does not increase to the overturning threshold during winter. At this threshold, deepwater formation and convection within the whole water column begin. A surface salinity decrease, linked either to a modest alteration of the long-term evaporation-precipitation (E-P) budget of the North Atlantic Ocean or to a reduced advection of saline subtropical water, would result in such a surface water density decrease. (E-P) changes would result in large-scale salinity changes, whereas advection changes would change salinity gradient. At present, both effects cannot be distinguished, 
because a reconstruction of the salinity field in the whole North Atlantic Ocean is not available. Using an oceanic general circulation model (OGCM), Maier-Reimer and Mikolajewicz [1989] showed that the thermohaline circulation ceases if the freshwater flux increases by a small amount $(0.1$ $\left.\mathrm{Sv}=10^{5} \mathrm{~m}^{3} \mathrm{~s}^{-1}\right)$. Recently, Stocker and Wright [1991] used an idealized ocean circulation model to show that a decrease of the atmospheric flux of freshwater from the Atlantic to the Pacific Ocean can reverse the Atlantic circulation (i. e. deep water would flow south to north), although the Pacific thermohaline circulation does not change direction. This pattern of circulation is consistent with reconstructions of conditions in the Atlantic Ocean during the last glacial maximum [Boyle and Keigwin, 1987; Duplessy et al., 1988].

The surface salinity of the North Atlantic Ocean is therefore a critical parameter in the understanding of oceanic feedbacks to climate changes. In this paper, we use isotopic analyses of planktonic foraminifera and micropaleontologic sea surface temperature (SST) estimates in a high sedimentation rate core raised off Portugal (core SU 81-18, 37 $46^{\circ} \mathrm{N}, 10^{\circ} 11^{\prime} \mathrm{W}, 3135$ $\mathrm{m})$ to reconstruct local variations in the surface water $\delta^{18} \mathrm{O}$ during the last 18,000 years. We successively estimate the effect on planktonic foraminifera $\delta^{18} \mathrm{O}$ of SST changes and input of meltwater with low $\delta^{18} \mathrm{O}$ values in the North Atlantic Ocean during the last deglaciation. We then calculate the seawater $\delta^{18} \mathrm{O}$ variations due to E-P and advection changes as the difference between the planktonic foraminiferal $\delta^{18} \mathrm{O}$ record from core SU 81-18 and the $\delta^{18} \mathrm{O}$ variations due to both temperature and ice volume changes. Because the seawater $\delta^{18} \mathrm{O}$ is linearly related to salinity (Craig's data cited by Broecker [1989, Figure 4]), this study provides a quantitative estimate of surface water conditions associated with the last deglaciation in the Northeastern Atlantic Ocean. This approach provides only a first-order sea surface salinity estimate since, within a basin, local changes of the slope of the $\delta^{18} \mathrm{O}$-salinity relationship have been observed [Duplessy, 1970; Fairbanks et al., 1992].

\section{STRATEGY}

The $\delta^{18} \mathrm{O}$ of planktonic foraminifera reflects a complex sum of fractionation processes, including the mean $\delta^{18} \mathrm{O}$ composition of the world ocean, the local temperature of calcite shell precipitation, the local E-P budget, and speciesspecific biological fractionation. Recently, Duplessy et al. [1991a] calibrated the $\delta^{18} \mathrm{O}$ value of $G$. bulloides against hydrographic data [Levitus, 1982] and showed that within its optimal summer temperature range $\left(7\right.$ to $\left.22^{\circ} \mathrm{C}\right)$, this species $\delta^{18} \mathrm{O}$ accurately records sea water temperature and $\delta^{18} \mathrm{O}$ variations. The isotopic temperature recorded by $G$. bulloides is, however, neither the summer (average of June, July and August) nor the mean annual temperature, because this species lives mainly at the end of the spring bloom when warm conditions and a strong thermocline exist [Reynolds-Sautter and Thunell, 1989]. A statistical analysis performed on $\delta^{\mathbf{1}} \mathrm{O}$ values of $G$. bulloides $(>150 \mu \mathrm{m}$ ) from 83 Holocene core tops distributed throughout the North Atlantic Ocean showed that the isotopic temperature indicated by $G$. bulloides (calculated using the paleotemperature equation of Shackleton [1974]) is highly correlated $\left(r^{2}=0.89\right)$ with the summer SST and is approximately equal to $\mathrm{T}^{*}=$ summer SST $-1^{\circ} \mathrm{C}$ [Duplessy et al., 1991a]. Consequently, $T^{*}$ represents a statistical estimate of the mean calcification temperature for the $G$. bulloides population under modern conditions. Outside of its optimal temperature range, the $\delta^{18} \mathrm{O}$ values of $G$. bulloides are more or less constant as already observed by Bard et al. [1988]. We shall assume here that the modern relationship linking the $\delta^{18} \mathrm{O}$ values of $G$. bulloides to summer SST remained constant in the past and that micropaleontologic transfer functions also provide correct estimates of past summer conditions [Duplessy et al., 1991a]. The first assumption implies that both the depth habitat and the life season of $G$. bulloides did not change. Uncertainties linked to these hypothesis have been discussed in detail by Mix and Ruddiman [1985] and Mix [1987], and we need to know more about the foraminiferal population dynamics to improve our understanding between transfer function temperatures and isotope effects.

In core SU 81-18, previously dated by ${ }^{14} \mathrm{C}$ accelerator mass spectrometry [Bard et al., 1987; Duplessy et al., 1991b], we considered two kinds of paleoclimatic records: paleotemperatures based on micropaleontological transfer functions and the oxygen isotope measurements $\left(\delta^{18} \mathrm{O}\right)$ performed on $G$. bulloides. All planktonic foraminiferal estimates of SST were based on census counts of 300 or more individuals representing the total planktonic foraminiferal population present. We applied a transfer function established by Pujol [1980], using the technique of Imbrie and Kipp [1971], which was calibrated with 261 core top samples distributed throughout the whole North Atlantic Ocean. Since this transfer function used 173 samples published by Kipp [1976] and 88 samples from the eastern Atlantic Ocean [Duplessy et al., 1973], it differs only slightly from that derived by Kipp [1976] [Pujol, 1980]. We compare (Figure 1) the variations of the summer temperature estimate for the surface water at the location of core SU 81-18 with the communality of the fossil population, which measures the degree of similarity of fossil assemblages with the reference data base. The communality is generally higher than 0.80 , except at some discrete levels where exceptionally

\section{Northeastern Atlantic Core SU 81-18}

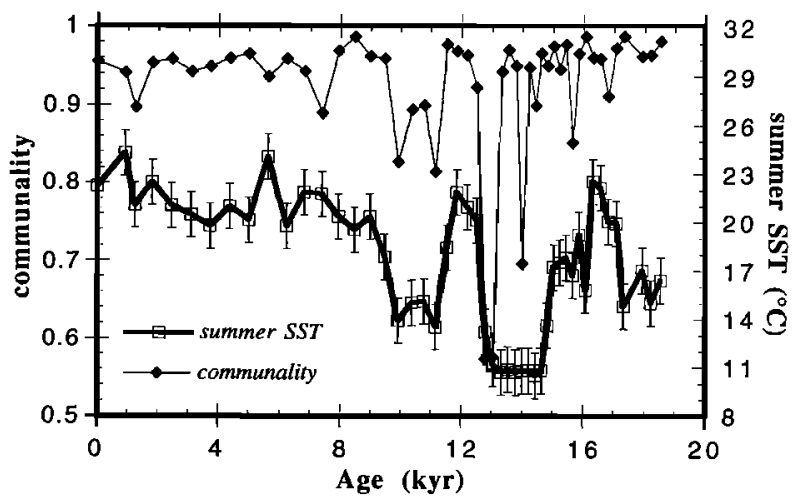

Fig. 1. Summer Sea Surface Temperature and faunal communality records from Northeastern Atlantic core SU 81-18. 
high amounts of $G$. quinqueloba occur (Figure 1). In the North Atlantic, other statistical approaches for estimating past SST from micropaleontological data have been tested by Prell [1985] who showed that all methods are consistent within their respective standard deviations when the communality is high. Although we did not apply the analog matching method of Prell [1985] to core SU 81-18, we consider that the SST estimates are reliable with a standard deviation of $1.4^{\circ} \mathrm{C}[\mathrm{Pujol}$, 1980].

Faunal SST estimates generally lie in the range 10 to $22^{\circ} \mathrm{C}$ during most of the last 18,000 years, which is within the optimal isotopic range of $G$. bulloides. Some warm events of short duration, during which SST was slightly warmer than $22^{\circ} \mathrm{C}$, were not considered in the following discussion, but their duration was so short that this simplification does not disturb the general picture obtained for the last deglaciation and the Holocene. These results indicate that the isotopic record of G. bulloides in core SU 81-18 should accurately register variations of the surface water $\delta^{18} \mathrm{O}$ and summer temperature. Following Imbrie et al. [1973] and Mix and Ruddiman [1985], the measured foraminiferal $\delta^{18} \mathrm{O}$ variations may thus be considered as the direct summation of three factors: (1) temperature variations which can be calculated by the paleotemperature equation [Epstein et al., 1953; Shackleton, 1974]; (2) ice volume, i.e. global seawater $\delta^{18} \mathrm{O}$ variations due to melting or growth of continental ice sheets; (3) local seawater $\delta^{18} \mathrm{O}$ variations due mainly to changes either in advection of saline/ $\delta^{18} \mathrm{O}$-high subtropical water or in the balance between evaporation and precipitation, as no major rivers are present in this area. We shall discuss successively the importance of these various environmental factors on the isotopic record of $G$. bulloides in core SU 81-18.

\section{IMPACT OF SST VARIATIONS}

In Model 1, we assume that $G$. bulloides grows its shell in isotopic equilibrium with ambient water at the temperature $\mathrm{T}^{*}$ $=$ summer $\mathrm{SST}-1^{\circ} \mathrm{C}$ and assume that the sea water experienced no $\delta^{18} \mathrm{O}$ change during the last 18,000 years. This model is clearly unrealistic but is useful to emphasize the importance of SST variations in the $\delta^{18} \mathrm{O}$ record. Estimates of summer paleotemperatures are those reported in Figure 1. The foraminiferal $\delta^{18} \mathrm{O}$ values are calculated by solving the paleotemperature equation, assuming that the salinity and seawater $\delta^{18} \mathrm{O}$ values were the same as today. Summer (J-J-A) salinities were derived from the Levitus [1982] atlas and the seawater $\delta^{18} \mathrm{O}$ values were calculated from the empirical relationship that links $\delta^{18} \mathrm{O}$ to salinity from the GEOSECS [1987] data (a detailed discussion is given by Duplessy et al. [1991a]). As the mean summer salinity is 36.1 at the location of core SU 81-18, we estimate the seawater $\delta^{18} \mathrm{O}$ value to be $0.88 \%$ with respect to the SMOW international standard. The foraminiferal $\delta^{18} \mathrm{O}$ values calculated in Model 1 are expressed with respect to the PDB international standard and are compared with the $\delta^{18} \mathrm{O}$ values of $G$. bulloides at the same core level in Figure 2. Although the two curves differ noticeably, they exhibit numerous common trends: despite the fact that we neglected in this model the seawater $\delta^{18} \mathrm{O}$ variations due to ice volume, cold temperature events coincide with high $\delta^{18} \mathrm{O} G$. bulloides values, whereas warm temperature events coincide
Core SU 81-18 compared to Model 1

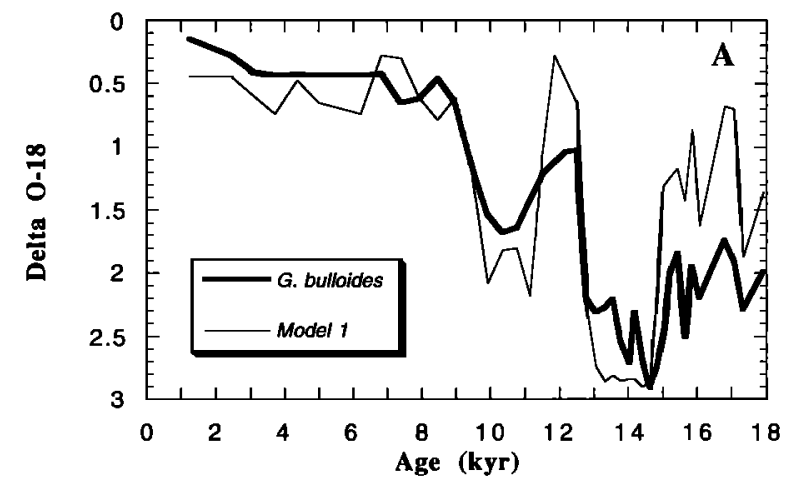

Core SU 81-18 compared to Model 2

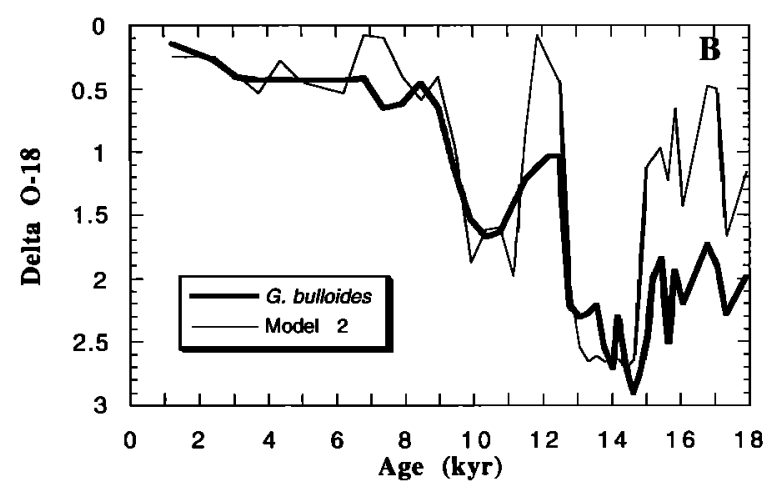

Fig. 2. Comparison of the $\delta^{18} \mathrm{O}$ variations of G. bulloides in core SU 81-18 (heavy line) with those calculated in Model 1 (thin line) assuming: (1) no seawater salinity/ $\delta^{18} \mathrm{O}$ variations, (2) that $G$. bulloides $\delta^{18} \mathrm{O}$ recorded the sea surface temperature variations, and (3) that the modern isotopic calibration of $G$. bulloides was valid during the last 18,000 years. (b) Comparison of the $\delta^{18} \mathrm{O}$ variations of $G$. bulloides in core SU 81-18 (heavy line) with those calculated in Model 2 (thin line). Model 2 has the same assumptions as Model 1 , and the calculated $\delta^{18} \mathrm{O}$ curve has been shifted by $0.2 \%$ o to fit the Holocene record of the last 7000 years.

with low $\delta^{18} \mathrm{O}$ values. Moreover, the transitions in the data and in the model are synchronous, indicating that the SST variations had a strong influence on the foraminiferal $\delta^{18} \mathrm{O}$ record.

The two curves in Figure 2 also do not coincide for the late Holocene as would be expected, because continental ice sheet melting was finished by about 7,000 yr BP. The calculated curve of Model 1 is on average heavier than the foraminiferal record by 0.2 per mil (equivalent to a temperature error of $0.8^{\circ} \mathrm{C}$ or a salinity error of 0.4 ) during the last 7000 years. The discrepancy is small and well within the uncertainties of our estimate of the modern seawater $\delta^{18} \mathrm{O}$ value and effective temperature of calcification $T^{*}$ [Duplessy et al., 1991a]. We therefore develop a second model to account for the temperature 
variations by shifting the curve of Model 1 by 0.2 per mil to fit the data for the last 7000 years. The curve obtained (Model 2 ) is compared with the $G$. bulloides $\boldsymbol{\delta}^{18} \mathrm{O}$ record in Figure 2. The two curves still disagree noticeably during the warm events (the combined Bolling/Allerod events, about 12,500 to 11,000 years ago), which occurred prior to 10,000 years BP.

\section{IMPACT OF CONTINENTAL ICE VOLUME VARIATIONS}

During the last deglaciation, meltwater was released mainly into the North Atlantic Ocean by direct calving of icebergs into the ocean [Ruddiman and McIntyre, 1981; Ruddiman and Duplessy, 1985; Duplessy et al., 1986], and by melting over the continent and transport by rivers. Runoff from the Laurentide ice sheet, the biggest of the last great ice sheets, drained into the Atlantic Ocean via the Mississippi River and the Saint Lawrence River [Emiliani et al., 1975; Kennett and Shackleton, 1975; Broecker et al., 1988, 1989]. The freshwater first mixed with surface water of the North Atlantic and then was progressively diluted in the other water masses at a rate depending primarily on that of the global ocean circulation.

Because mixing within the global ocean is not instantaneous, but requires several centuries, the meltwater curve based on ${ }^{14} \mathrm{C}$ ages of reef crest corals from Barbados [Fairbanks, 1989] cannot be directly converted into a sea water dilution curve valid for the North Atlantic Ocean. We therefore used a simple box model [Duplessy et al., 1991b; Bard et al., $1991]$ to estimate the surface water $\delta^{18} 0$ of the North Atlantic, assuming that it was a well-mixed reservoir and used the meltwater curve of Fairbanks [1989] as an input function for the model (Figure 3). The model has four oceanic boxes: Surface Atlantic (SA), Deep Atlantic (DA), Surface IndoPacific (SIP), and Deep Indo-Pacific (DIP), which have realistic volumes derived from the Pandora model used by Broecker and Peng [1986]. The main circulation pattern is a simple thermohaline loop in which water moves from SA to DA, and then to DIP, SIP and back to SA. The atmosphere is a simple well-mixed box that exchanges with the two oceanic surface boxes. This simple model converges toward realistic radiocarbon contents for deep waters when the residence time of the surface water of the Atlantic is of the order of 40-50 years (see details in the work by Bard et al. [1991] and Duplessy et al. [1991b]). The calculated residence time of SA (46 years) is in agreement with the tritium- ${ }^{3} \mathrm{He}$ distribution [Ostlund et al, 1987] and is equivalent to a production of North Atlantic Deep Water (NADW) of $28 \mathrm{~Sv}$, which is close to the modern values determined from the radiocarbon budget of the Atlantic Ocean which lie between 14 and $30 \mathrm{~Sv}$ [Broecker, 1979; Warren, 1981].

The meltwater input is reported in Figure 3. The $\delta^{18} \mathrm{O}$ input curve has been constructed by means of the sea level record from Barbados. In addition to the initial ${ }^{14} \mathrm{C}$ data presented by Fairbanks [1989], we also took into account further analyses obtained by the Tandetron accelerator mass spectrometer at Gif [Bard et al, 1990; Fairbanks, 1990]. All data are reported in radiocarbon years.

In Model 3, we assumed that the isotopic composition of the ice sheet was homogeneous and calculated the seawater $\delta^{18} \mathrm{O}$ variations for various residence times of Surface Atlantic water ranging from 10 to 150 years. These upper and lower

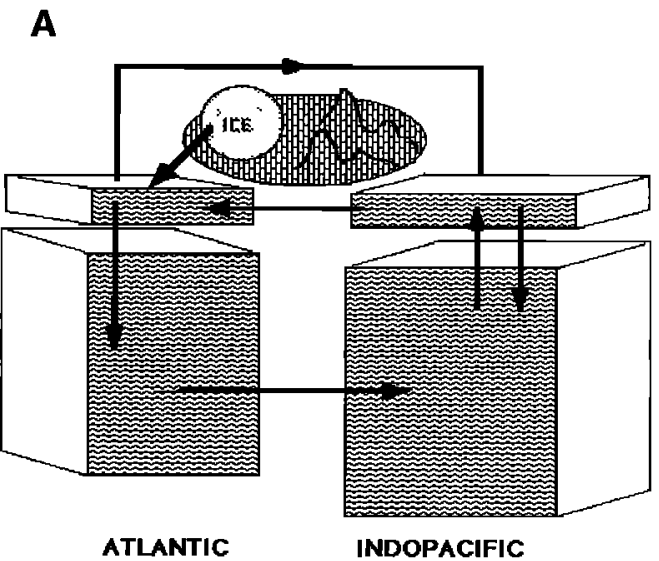

B

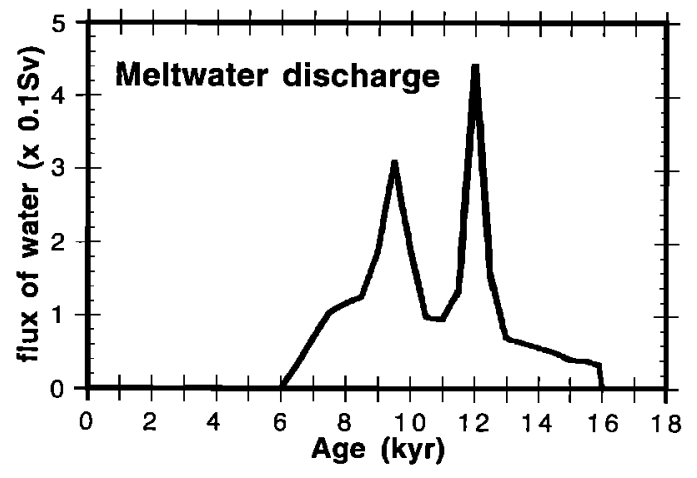

Fig. 3. (a) Schematic diagram of the main pathways for the isotopic signal during the deglaciation. This diagram also represents the box model used for the simulations of the last deglaciation. (b) Melting rate during the last deglaciation used as input function in the four-box model. This curve was obtained by calculating the derivative of the Barbados sea level versus age curve [Fairbanks, 1989].

values are clearly much more extreme than those expected from the changes in circulation rates estimated by Duplessy et al. [1991b], but they are useful for showing the upper limits of the surface water $\delta^{18} \mathrm{O}$ variations during the last deglaciation. In Model 4, we performed the same calculations, but took into account the lag predicted by Mix and Ruddiman [1984] between the sea level and the sea water $\delta^{18} \mathrm{O}$ signals. Because the ice caps were isotopically heterogeneous during the last glacial maximum, the ice which melted during the early phase of the last deglaciation was less depleted in ${ }^{18} \mathrm{O}$ than during the end of the climatic transition. We simply assumed that the $\delta^{18} \mathrm{O}$ of meltwater varied linearly through volume from $-20 \%$ to $-40 \%$ o as ice melted. In both models, we normalized the amplitude of the mean global seawater $\delta^{18} \mathrm{O}$ variation between the beginning ( 16000 years ago) and the end of the deglaciation ( 6000 years ago) to $1.2 \%$, the mean value of estimates obtained using three independent methods by Labeyrie at al. [1987], Shackleton [1987], and Fairbanks [1989].

Temporal variations of the Atlantic surface water $\delta^{18} O$ due to the melting of continental ice sheets are reported in Figure 4 (Model 3 for an homogenous ice sheet and Model 4 for an 
Deglaciation of an Homogeneous ice sheet

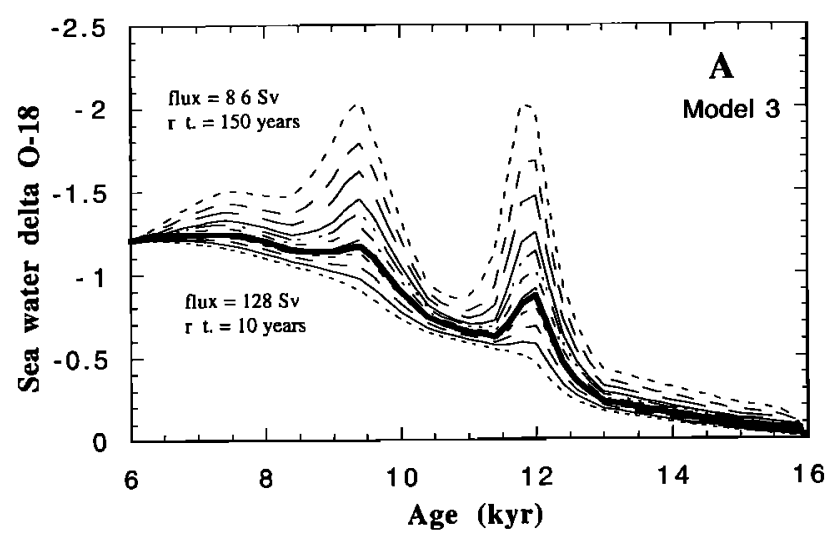

Deglaciation of an heterogeneous ice sheet

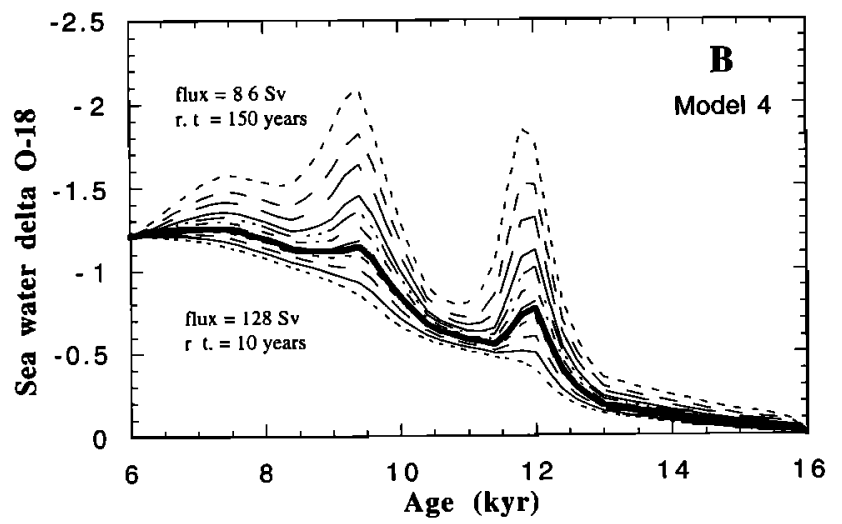

Fig. 4. Temporal variations of Atlantic surface water $\delta^{18} \mathrm{O}$ due to the melting of continental ice sheets for different rates of ocean circulation and for isotopically (a) homogenous and (b) heterogenous ice sheets. The following residence times for surface water have been considered: $10,20,30,40,46$ (modern value), 50, 60, 70, $80,90,100,120$, and 150 years. A residence time of 10 years is equivalent to a NADW flux of $128 \mathrm{~Sv}$, whereas a residence time of 150 years is equivalent to a NADW flux of $8.6 \mathrm{~Sv}$. The heavy curves correspond to the modern value of oceanic circulation (residence time of 46 years equivalent to a NADW flux of $28 \mathrm{~Sv}$ ).

heterogenous ice sheet) for NADW circulation rates varying from 8.6 to $128 \mathrm{~Sv}$. As the two sets of curves corresponding to Models 3 and 4 are rather similar, we compared in Figure 5 the deglaciation curves corresponding to three cases of ocean circulation: the present one (residence time of 46 years for the Surface Atlantic reservoir equivalent to a NADW flux of 28 $\mathrm{Sv}$ ), a very slow oceanic circulation (residence time of 150 years for the Surface Atlantic reservoir equivalent to a NADW flux of $8.6 \mathrm{~Sv}$ ) and a fast circulation (residence time of 10 years for the Surface Atlantic reservoir equivalent to a NADW flux of $128 \mathrm{~Sv}$ ). The $\delta^{18} \mathrm{O}$ signal associated with the melting of an heterogeneous ice sheet (Model 4) is indeed slightly delayed and has a slightly smaller amplitude at the beginning of the deglaciation (Figure 5) than that corresponding to the melting of an homogeneous ice sheet (Model 3). However, the differences between curves corresponding to Models 3 and 4 are rather small, and within error of analysis, we cannot distinguish between homogenous and heterogenous ice sheets. These differences are also negligible with respect to those related to changes in the ocean circulation rate. Our model is rather crude. However, our conclusions are not changed using more complex and more realistic models, such as the Pandora model of Broecker and Peng [1986].

In Models 3 and 4, each main meltwater event recognized by Fairbanks [1989] is associated with a negative $\delta^{18} \mathrm{O}$ peak, whose amplitude decreases with increasing rate of ocean circulation and decreasing residence time for the Surface Atlantic reservoir (Figure 6). These peaks are clearly distinguishable for rates similar to or slower than the present one and become shoulders on the deglaciation curve if the residence time of Surface Atlantic water is smaller than at present by a factor of 2 (Figure 4). The deglacial records depicted by Models 3 and 4 are those expected from Atlantic planktonic foraminifera if sea surface temperature and local salinity variations were negligible.

\section{THE COMPLETE DEGLACIATION RECORD}

\section{Evidence for Seawater $\delta^{18} O$ Variations due to E-P and Advection Changes}

It is not possible to make an estimate of the local seawater $\delta^{18} \mathrm{O}$ variations due to salinity changes without making an assumption of the rate of oceanic circulation (which drives the distribution of the meltwater in the world ocean) and an additional assumption of the $\delta^{18} \mathrm{O}$ of the meltwater itself. Therefore we shall first calculate whether it is possible to make a model of the deglaciation with a realistic flux for the oceanic Conveyor Belt assuming that changes of both the local E-P budget and subtropical water advection were negligible, i.e.,

Comparison of the melting of an homogeneous and an heterogeneous $(\mathrm{He})$ ice sheet

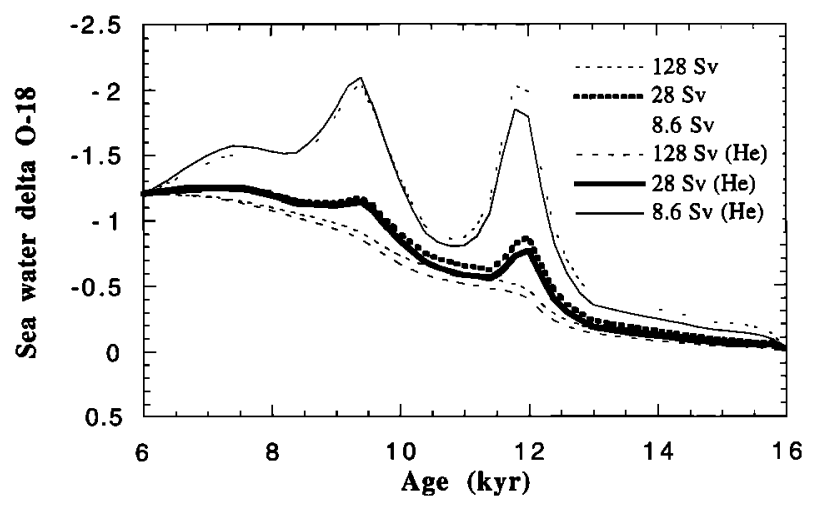

Fig. 5. Comparison of the seawater $\delta^{18} \mathrm{O}$ variations corresponding to the melting of an isotopically homogenous and an heterogenous ice sheet for three different rates of ocean circulation (8.6 Sv, $28 \mathrm{~Sv}$, and 128 $\mathrm{Sv}$ ). 

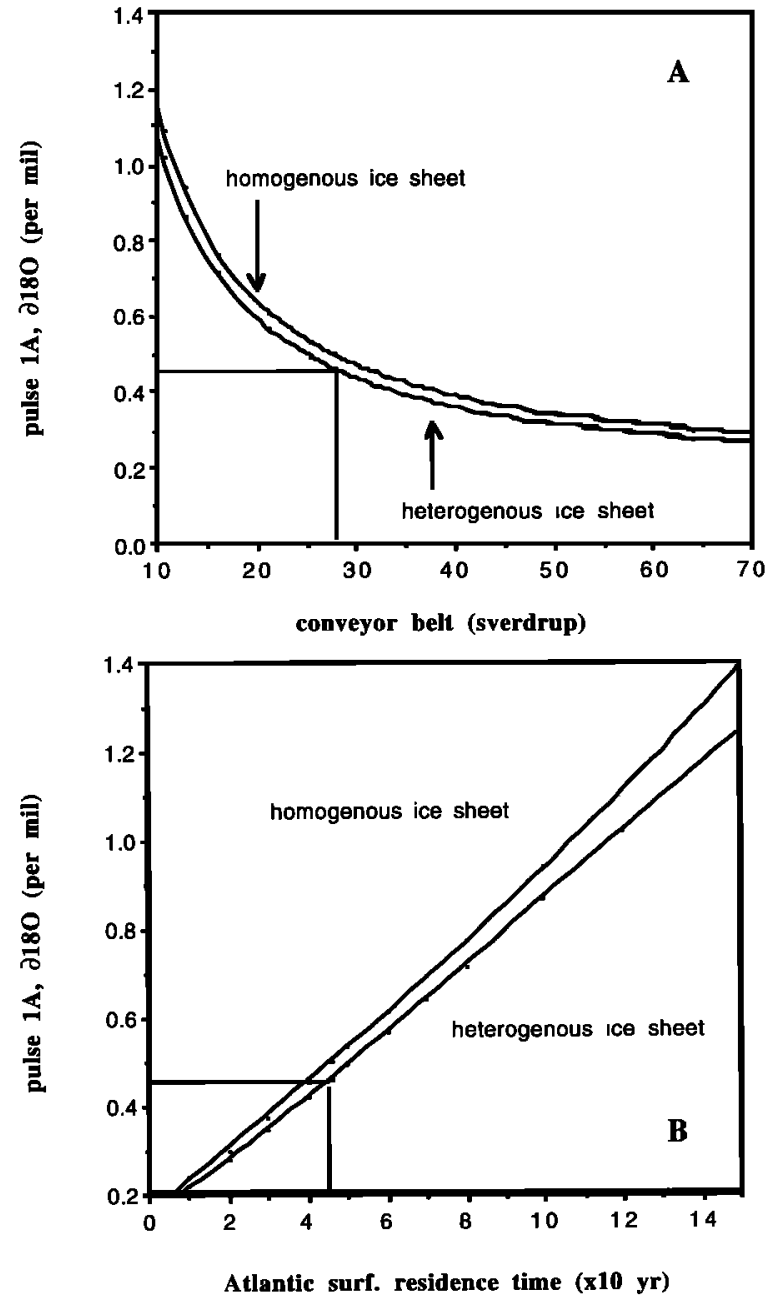

Fig. 6. Amplitude of the $\delta^{18} \mathrm{O}$ pulse associated with Termination $\mathrm{I}_{\mathrm{A}}$ versus (a) the rate of ocean circulation and (b) the residence time of water in the Surface Atlantic reservoir. Note the slight amplitude reduction associated with the melting of an heterogenous versus an homogenous ice sheet.

that the sea surface salinity gradients have been the same as today during the whole deglaciation. Because $G$. bulloides in core SU 81-18 has recorded both temperature and seawater $\delta^{18} \mathrm{O}$ variations due to the melting of continental ice sheets, such a model of the complete $\delta^{18} \mathrm{O}$ record of the deglaciation is obtained by summing the records obtained in Models 2 and 3 if we assumed an homogeneous ice sheet (Model 5) and by summation of the records obtained in Models 2 and 4, if we assume an heterogeneous ice sheet (Model 6). Both models are compared to the measured record of $G$. bulloides in Figure 7 . Regardless of the model used for the comparison and of the value of the NADW flux, the calculated records do not fit the data: they are isotopically heavier than the measured values during cold episodes (the Younger Dryas, 11-10 kyr ago and the end of isotope stage 2, about 15 to $13 \mathrm{kyr}$ ago) and lighter than the measured values during the warm Bolling/Allerod event
12.5-11 kyrs ago. The disagreement between Models 5 or 6 and the data means that the surface water at the location of core SU 81-18 experienced $\delta^{18} \mathrm{O}$ changes due to both ice sheet melting and local changes of E-P.

\section{Estimate of $\delta^{l}{ }^{8} O$ Variations due to E-P and Advection Changes}

In order to estimate the $\delta^{18} \mathrm{O}$ changes experienced by surface water during the deglaciation, we made the following calculations:

1. We first calculated the planktonic foraminiferal $\delta^{18} \mathrm{O}$ variation due to the summer sea surface temperature variations reported in Figure 1 using the paleotemperature equation and Model 2.

2. We then calculated the North Atlantic surface water $\delta^{18} \mathrm{O}$ variations due to ice sheet melting using the box model and the meltwater input reported in Figure 3. In order to take into account the heterogeneity of the ice sheets, we assumed that the $\delta^{18} \mathrm{O}$ of meltwater varied linearly from $-20 \%$ to $-40 \%$ o when the ice melted. We also assumed that the flux of NADW,
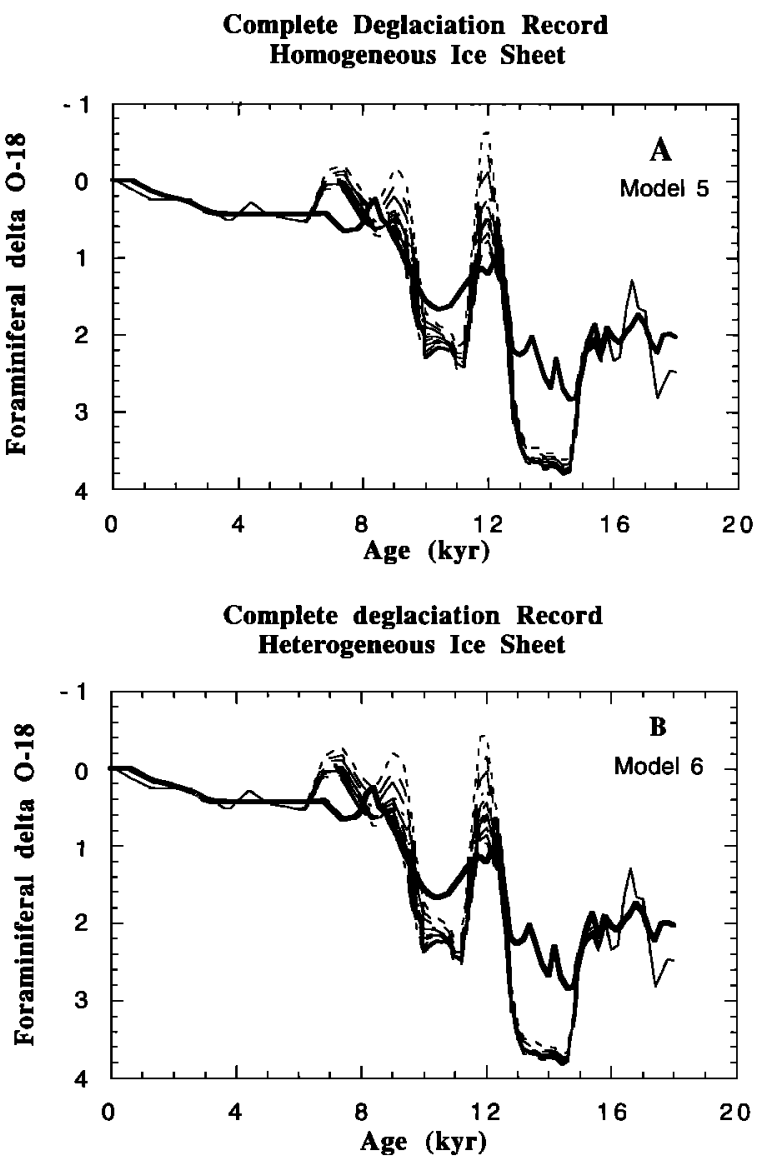

Fig. 7. Comparison of the $\delta^{18} \mathrm{O}$ of $G$. bulloides from core SU 81-18 (heavy line) with the $\delta^{18} \mathrm{O}$ record calculated assuming that this species registered only temperature and ice volume effects. Melting of an isotopically (a) homogenous and (b) heterogenous ice sheet are considered. 

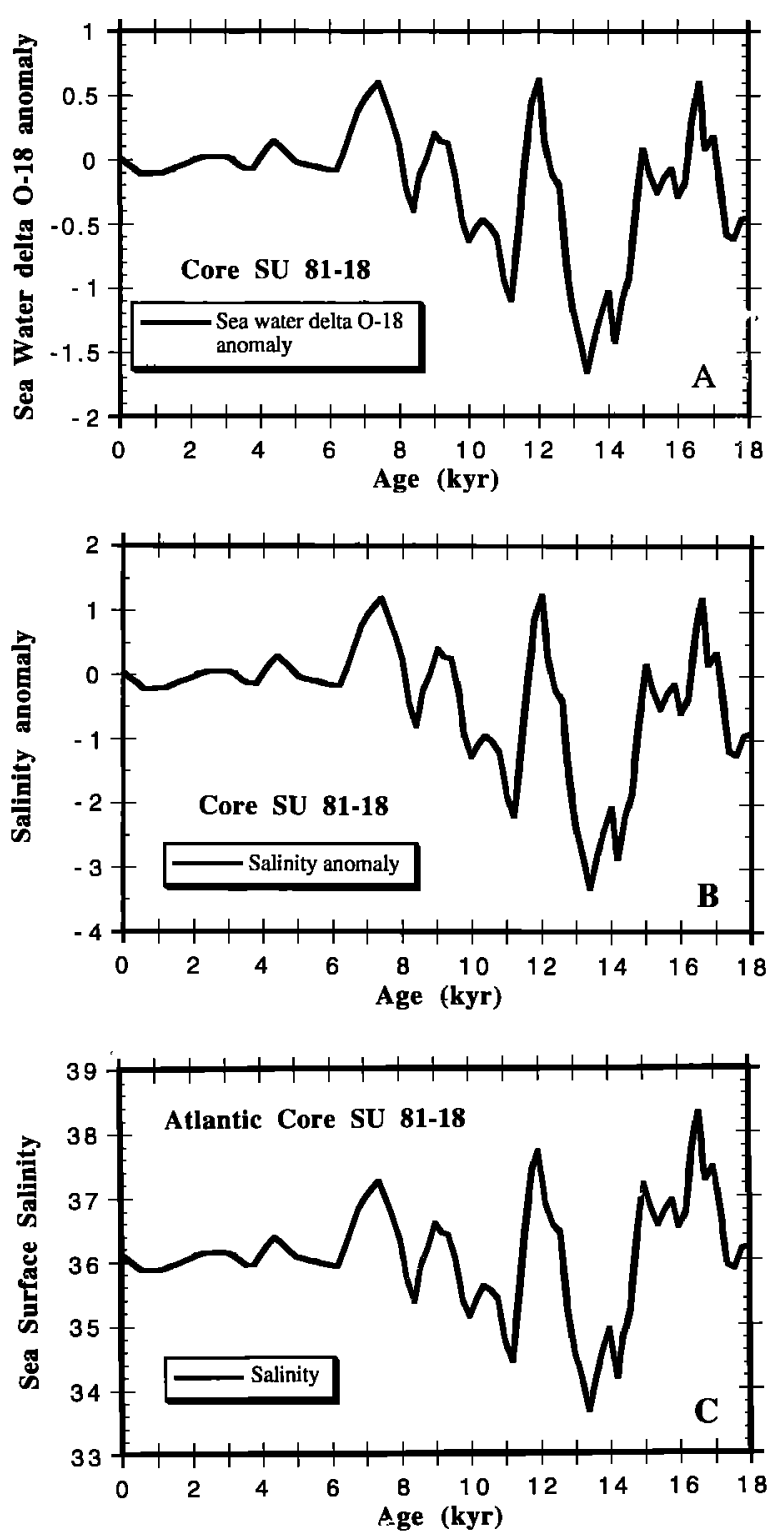

Fig. 8. (a) Seawater $\delta^{18} \mathrm{O}$ and (b) salinity anomalies during the deglaciation. (c) The salinity estimate takes into account all the causes of sea surface salinity changes (meltwater input and changes in the hydrological cycle).

which drives the residence time of surface Atlantic water in the box model, was the same as today during the last deglaciation; this is the most conservative hypothesis which takes into account the chronologies of the deglaciation records of the different oceanic basins [Duplessy et al., 1991b].

3. We finally calculated the local seawater $\delta^{18} O$ variations due to changes of both the local E-P budget and subtropical water advection as the $\delta^{18} \mathrm{O}$ difference between the measured G. bulloides record (interpolated every 200 years) and the $\delta^{18} \mathrm{O}$ record calculated by summing the effects of both SST variations and ice melting. This is called the $\delta^{18} \mathrm{O}$ anomaly and is reported in Figure 8. The main trends of this record, and in particular the negative anomalies observed 13,000 to 14,000 years ago and during the Younger Dryas event, are robust features. They do not depend on the assumptions made either on the isotopic composition of the melting ice sheet (they are present if we assume that the ice sheet was homogenous) or on the rate of deepwater formation in the North Atlantic (they are present even if we assume that it changed by as much as $100 \%)$.

\section{Estimate of Sea Surface Salinity Changes}

The $\delta^{18} \mathrm{O}$ variations experienced by surface seawater reflect salinity changes. In order to calculate them, we must take into account the fact that continental ice melting and E-P changes result in different $\delta^{18} \mathrm{O} /$ salinity relationships:

1. We calculated the salinity change linked to the ice volume variation using the sea level record of Fairbanks [1989] and assuming that salinity decreased by $1 \%$ oduring the whole deglaciation.

2. We calculated the local salinity anomaly due to E-P changes assuming that a sea water $\delta^{18} \mathrm{O}$ anomaly of $1 \%$ is equivalent to a salinity anomaly of $2 \%$ [Craig and Gordon, 1965]. The salinity anomaly is reported in Figure 8.

3. The salinity record at the location of core SU 81-18 during the deglaciation (Figure 8 ) may be calculated by adding to the modern salinity value the variations due to both ice melting and changes of the local E-P budget and/or subtropical water advection (i.e. the salinity anomaly).

\section{DISCUSSION}

We compared the sea surface temperature record with the salinity anomaly and with the sea surface salinity record in Figure 9. During the whole deglaciation, warm water masses had high salinity, whereas cold water masses had low salinity. The radiocarbon dating of core SU 81-18 and that of the Barbados sea level record [Fairbanks, 1989] indicate a synchroneity between the onset of warm conditions in the surface waters and the major melting phase of the Laurentide ice-sheet. Despite the influx of meltwater during the Bolling/Allerod warm event, the northeastern Atlantic Ocean was then saltier than it is today. By contrast, the surface Atlantic was fresher than today during the cold Younger Dryas event, although the rate of ice sheet melting was smaller than before.

Similar temperature and salinity changes during the last deglaciation were observed in the North Atlantic and in the Norwegian Sea [Duplessy et al., 1992]. This suggests that hydrographic changes in the North Atlantic Ocean are best explained as the migration of a front separating warm highsalinity from cold low-salinity water masses, of which the characteristics depend on their coupling with the atmosphere (exchanged heat flux, E-P budget). These results support the temperature/salinity link assumed by Boyle and Keigwin [1987] to explain the formation of intermediate water in the North Atlantic Ocean during glacial conditions. They disagree with the speculation made by Fairbanks [1990] that lowsalinity conditions would be created in the North Atlantic 
Temperature and salinity anomaly records

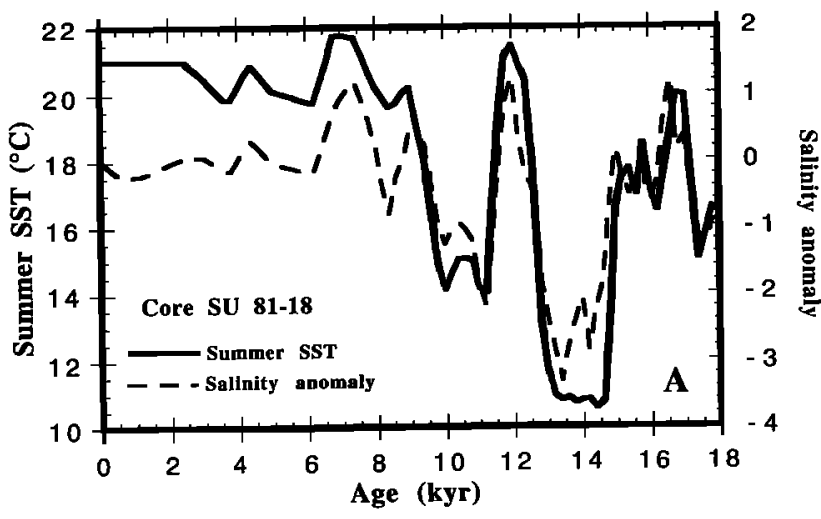

Temperature and salinity Records

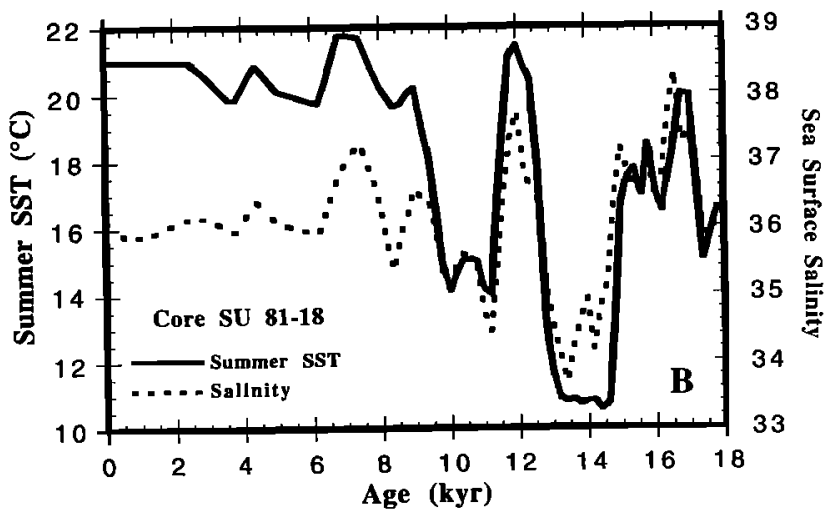

Fig. 9. (a) Summer sea surface temperature and salinity anomaly estimates from northeastern Atlantic core SU 81-18. Interpolated values have been calculated every 200 years. The salinity anomaly is defined as the local surface water salinity variation due to changes in the evaporation - precipitation. (b) Summer sea surface temperature and salinity estimates from northeastern Atlantic core SU 81-18. Interpolated values have been calculated every 200 years.

during warm periods of rapid ice sheet melting and would have inhibited the production of NADW.

Temperature and salinity variations occurred synchronously (Figure 9). This reconstitution supports the simple view of salinity variations due to the migration of a front separating warm high-salinity from cold low-salinity water masses, but it should be kept in mind that the salinity of these water mass are strongly dependent on the local E-P budget. We did not detect any lag between temperature and salinity changes. In order to explain the major climatic variations which occurred during the last deglaciation, Broecker et al. [1990] assumed that significant salinity changes preceded major temperature variations by about 1000 years. Such events would have been detected in the high-resolution record of core SU 81-18 because the sedimentation rate is $35 \mathrm{~cm} / \mathrm{kyr}$ for sediments older than
9300 years. Assuming a bioturbation thickness of $10 \mathrm{~cm}$, a first-order model gives a theoretical attenuation of only $25 \%$ for a signal half-period of 1000 years [Bard et al., 1987]. However, our data do not exclude the possibility that significant salinity changes occurred before temperature changes and that the "Atlantic salt oscillator" mechanism may be correct. They provide a severe constraint on the time constant of sea surface salinity variations and imply that the lead of salt versus temperature has been shorter than a few centuries.

\section{CONCLUSION}

The oxygen isotope record of the planktonic foraminifer $G$. bulloides registers both temperature and seawater $\delta^{18} \mathrm{O}$ variations when the foraminiferal species precipitates calcite within its optimal temperature range. Consequently, a detailed comparison of biotic SST estimates and $\delta^{18} \mathrm{O}$ variations in a core provides a tool for estimating surface salinity variations at the core location.

The northeastern Atlantic Ocean experienced strong salinity changes during the deglaciation. However, despite freshwater input due to ice cap melting, the salinity reduction during warm events of the last 18,000 years was smaller than the salinity enhancement due to the local inflow of warm saline water. Although it does not explain the physical mechanism involved in producing the hydrographic changes, the migration of a front separating warm saline water from fresher and colder polar water is one likely scenario for explaining the paleoceanographic changes associated with the last glacial to interglacial transition.

Acknowledgments. Thanks are due to E. Boyle, S. Calvert, W. Howard K. Miller and A. Mix for reviewing carefully this manuscript, to E. Birchfield for useful comments, and to J. Antignac, B. Le Coat, H. Leclaire, P. Maurice and E. Kaltnecker for help in the analysis. This research was supported by EEC, PNEDC, CNRS and CEA. This is CFR contribution 1343 .

\section{REFERENCES}

Bard E., M. Arnold, P. Maurice, J. Duprat, J. Moyes and J. C. Duplessy, Retreat velocity of the North Atlantic polar front during the last deglaciation determined by ${ }^{14} \mathrm{C}$ accelerator mass spectrometry, Nature, 328, 791-794, 1987.

Bard, E., B. Hamelin, R. G. Fairbanks, A. Zindler, M. Arnold, and $G$. Mathieu, $U / T h$ and ${ }^{14} \mathrm{C}$ ages of corals from Barbados and their use for calibrating the ${ }^{14} \mathrm{C}$ time scale beyond 9000 years, Nucl. Inst. Meth., 52, 461-468, 1990.

Bard, E., M. Arnold, and J. C. Duplessy, Reconciling the sealevel record of the last deglaciation with the $\delta^{18} \mathrm{O}$ spectra from deep sea cores, Quat. Proc., 1, 67-73, 1991.

Berger, W. H., The Younger Dryas cold spell - a quest for cause, Palaeogeogr. Palaeoclimatol. Palaeoecol., 89, 219237, 1990.

Boyle, E. A., and L. D. Keigwin, North Atlantic thermohaline circulation during the last 20,000 years: Link to high latitude surface temperature, Nature, 330, 35-40, 1987. 
Broecker, W. S., A revised estimate for the radiocarbon age of North Atlantic Deep Water, J. Geophys. Res., 84, 32183226, 1979.

Broecker, W. S., The salinity contrast between the Atlantic and Pacific oceans during the glacial time, Paleoceanography, 4, 207-212, 1989.

Broecker, W. S., and G. H. Denton, The role of oceanatmosphere reorganization in glacial cycles, Geochim. Cosmochim. Acta, 53, 2465-2501, 1989.

Broecker, W. S., and T. H. Peng, Carbon cycle: Glacial to interglacial changes in the operation of the global carbon cycle, Radiocarbon, 28, 309-327, 1986.

Broecker, W. S., M. Andree, W. Wolfli, H. Oeschger, G. Bonani, J. Kennett, and D. Peteet., The chronology of the last deglaciation: implications to the cause of the Younger Dryas event, Paleoceanography, 3, 1-19, 1988.

Broecker, W. S., J. P. Kennett, J. Teller, S. Trumbore, G. Bonani, and W. Wolfli, The routing of Laurentide ice-sheet meltwater during the Younger dryas cold event, Nature, 341, 318-321, 1989.

Broecker, W. S., G. Bond, M. Klas, G. Bonani, and W. Wolfli, A salt oscillator in the glacial northern Atlantic? I, The concept, Paleoceanography, 5, 469-477, 1990.

CLIMAP Project Members, The surface of the Ice Age Earth, Science, 191, 1131-1137, 1976.

CLIMAP Project Members, Seasonal reconstructions of the earth's surface at the last glacial maximum, Geol. Soc. Am. Map Chart Ser., MC-36, 1981.

Craig H., and L. I. Gordon, Deuterium and oxygen 18 variations in the ocean and the marine atmosphere, in Stable Isotopes in Oceanographic Studies and Paleotemperatures, edited by E. Tongiorgi, pp. 9-130, Consiglio Nazionale di Ricerche, Pisa, Italy, 1965.

Duplessy J. C., Note préliminaire sur les variations de la composition isotopique des eaux superficielles de l'Océan Indien : la relation ${ }^{18}$ O-salinité, C. R. Acad. Sci., 27I, 1075-1078, 1970.

Duplessy, J. C., G. Delibrias, J. L. Turon, C. Pujol, and J. Duprat, Deglacial warming of the northeastern Atlantic Ocean: Correlation with the paleoclimatic evolution of the European continent, Palaeogeogr., Palaeoclim., Palaeoecol. 35, 121-144, 1981.

Duplessy, J. C., M. Arnold, P. Maurice, E. Bard, J. Duprat, and J. Moyes, Direct dating of oxygen-isotope record of the last deglaciation by C-14 accelerator mass spectrometry, Nature, 320, 350-352, 1986.

Duplessy, J. C., N. J. Shackleton, R. G. Fairbanks, L. Labeyrie, D. Oppo, and N. Kallel, Deepwater source variations during the last climatic cycle and their impact on the global deepwater circulation, Paleoceanography, 3, 343$360,1988$.

Duplessy, J. C., L. Labeyrie, A. Juillet-Leclerc, F. Maitre, J. Duprat, and M. Sarnthein, Surface salinity reconstruction of the North Atlantic Ocean during the last glacial maximum, Oceanol. Acta, 14, 311-324, 1991a.

Duplessy, J. C., E. Bard, M. Arnold, N. J. Shackleton, J. Duprat, and L. D. Labeyrie., How fast did the oceanatmosphere system run during the last deglaciation?, Earth Planet. Sci. Lett., 103, 41-54, 1991 b.
Duplessy, J. C., L. Labeyrie, A. Juillet-Leclerc, and J. Duprat, A new method to reconstruct sea surface salinity: Application to the North Atlantic Ocean during the Younger Dryas, in The Last Deglaciation: Absolute and Radiocarbon Chronologies, edited by E. Bard and W. S. Broecker, Springer-Verlag, New York, pp. 201-217, 1992.

Emiliani, C., Pleistocene temperatures, J. Geol., 63, 538-578, 1955.

Emiliani, C., S. Gartner, B. Lidz, K. Eldridge, D. K. Elvey, T. S. Huang, J. J. Stipp, and M. F. Swanson, Paleoclimatic analysis of Late Quaternary cores from the northeastern Gulf of Mexico, Science, 189, 1083-1088, 1975.

Epstein S., R. Buchsbaum, H. A. Lowenstam, and H. C. Urey, Revised carbonate-water isotopic temperature scale, Geol. Soc. Am. Bull., 64, 1315-1325, 1953.

Fairbanks, R. G., A 17,000-year glacio-eustatic sea level record : influence of glacial melting rates on the Younger Dryas event and deep-ocean circulation, Nature, 342, 637642, 1989.

Fairbanks, R. G., The age and origin of the "Younger Dryas" climate event in Greenland ice cores, Paleoceanography, 5, 937-948, 1990.

Fairbanks, R. G., C. D. Charles, and J. D. Wright, Origin of global meltwater pulses, in Radiocarbon after four decades, edited by R. E. Taylor, A. Long, and R. S. Kra, pp. 473500, Springer-Verlag, New York, 1992.

GEOSECS, Atlantic, Pacific and Indian Ocean Expeditions, Vol. 7, Shorebased Data and Graphics, edited by GEOSECS Executive Committee H. G. Ostlund, H. Craig, W. S. Broecker, and D. Spencer, National Science Foundation, Washington, D. C., 1987.

Hammer, C. U., H. B. Clausen, W. Dansgaard, A. Neftel, P. Kristindottir and E. Johnson, Continuous impurity analysis along the Dye-3 deep core. in Greenland Ice Core: Geophysics, Geochemistry and the Environment, Geophys. Monogr. Ser, vol. 33, edited by C. C. Langway, H. Oeschger and W. Dansgaard, pp. 90-94, AGU, Washington, D. C., 1985.

Hays, J. D., J. Imbrie, and N. J. Shackleton, Variations in the Earth's orbit: Pacemaker of Ice Ages, Science, 194, 11211132, 1976.

Imbrie, J., and J. Z. Imbrie, Modelling the climatic response to orbital variations, Science, 202, 943-953, 1980.

Imbrie, J., and N. G. Kipp, A new micro-paleontological method for quantitative paleoclimatology: Application to a late pleistocene Caribbean core. in The Late Cenozoic Glacial Ages, edited by K. K. Turekian, pp. 71-181, Yale University Press, New Haven, Conn., 1971.

Imbrie, J., J. van Donk, and N. G. Kipp, Paleoclimatic investigations of a late Pleistocene Caribbean deep-sea core: Comparison of isotopic and faunal methods, Quat. Re., 3, 10-38, 1973.

Imbrie, J., J. D. Hays, D. G. Martinson, A. McIntyre, A. Mix, J. J. Morley, N. Pisias, W. Prell, and N. J. Shackleton, The orbital theory of Pleistocene climate: Support from a revised chronology of the late marine $\delta^{18} \mathrm{O}$ record, in Milankovitch and Climate, edited by A. Berger et al., pp. 269-305, D. Reidel, Hingam, Mass., 1984.

Imbrie, J., A. McIntyre, and A. Mix, Oceanic response to orbital forcing in the Late Quaternary; Observational and 
experimental strategies, in Climate and Geosciences, edited by A. Berger et al, pp. 121-164, Kluwer Academic, Boston, Mass., 1989.

Kennett, J. P,. and N. J. Shackleton, Laurentide ice-sheet meltwater recorded in Gulf of Mexico deep sea cores, Science, 188, 147-150, 1975.

Labeyrie, L. D., J. C. Duplessy, and P. L. Blanc, Variations in mode of formation and temperature of oceanic deep waters over the past 125,000 years, Nature, 327, 477-482, 1987.

Levitus S., Climatological atlas of the world ocean, NOAA Prof. Pap. 13, Natl. Oceanic and Atmos. Admin., Rockville, Md., 1982.

Maier-Reimer, E., and U. Mikolajewicz, Experiments with an OGCM on the cause of the Younger Dryas, in Oceanography, edited by A. Ayala-Castanares, W. Wooster and A. Yanez-Arancibia, pp. 87-100, UNAM Press, Mexico, 1989.

Mangerud, J., Late Weichselian vegetation and ice front oscillations in the Bergen District, Western Norway, Nor. Geogr. Tidsskr., 24, 121-148, 1970.

Milankovitch, M., Mathematische Klimalehre und astronomische Theorie der Klimaschawankungen, in Handbuch der Klimatologie, vol. IA, edited by W. Köppen and R. Geiger, pp. 1-176, Gebruder Bortraeger, Berlin, 1930.

Mix, A., The oxygen-isotope record of glaciation, vol. K-3, North America and Adjacent Oceans During the Last Deglaciation, pp. 111-135, Geological Society of America, Boulder, Col., 1987.

Mix, A., and W. F. Ruddiman, Oxygen-isotope analysis and Pleistocene ice volumes, Quat. Res., 21, 1-20, 1984.

Mix, A., and W. F. Ruddiman, Structure and timing of the last deglaciation: oxygen-isotope evidence, Quat. Sci. Rev., 4, 59-108, 1985.

Ostlund H. G., H. Craig, W. S. Broecker, and D. Spencer, GEOSECS Atlantic, Pacific and Indian oceans expeditions: Shorebased Data and Graphics, U. S. Government Printing Office, Washington, D. C., 1987.

Prell W. L., The stability of low-latitude sea-surface temperatures: An evaluation of the CLIMAP reconstruction with emphasis on the positive SST anomalies, Rep. DOE/ER/60167-1, Dep. of Energy, Washington, D. C., 1985.

Pujol, C., Les foraminiferres planctoniques de l'Atlantique Nord au quaternaire, écologie, stratigraphie, environnement, thesis, Univ. of Bordeaux I, France, 1980.
Reynolds-Sautter, L. A., and R. C. Thunell, Seasonal succession of planktonic foramnifera : Results from a fouryear time-series sediment trap experiment in the Northeast Pacific, J. Foraminiferal Res., 19, 253-267, 1989.

Ruddiman, W. F., and J. C. Duplessy, Conference on the last deglaciation: timing and mechanism, Quat. Res., 23, 1-17, 1985,

Ruddiman, W. F., and A. McIntyre, The north Atlantic Ocean during the last deglaciation, Palaeogeogr. Palaeoclimatol. Palaeoecol., 35, 145-214, 1981.

Shackleton, N. J., Attainment of isotopic equilibrium between ocean water and the benthonic foraminifera genus Uvigerina: Isotopic changes in the ocean during the last glacial, Colloq. CNRS 219, pp. 203-210, Cent. Natl. de la Rech. Sci., Paris, 1974.

Shackleton, N. J., Oxygen isotopes, ice volume and sea-level, Quat. Sci. Rev., 6, 183-190, 1987.

Stocker, T. F., and D. G. Wright, Rapid transitions of the ocean's deep circulation induced by changes in surface water fluxes, Nature, 351, 729-732, 1991.

Warren, B. A., Deep circulation of the world ocean, in Evolution of Physical Oceanography, Scientific Surveys in Honor of Henry Stommel, edited by B. A. Warren and C. Wunsch, pp. 6-41, MIT Press, Cambridge, Mass., 1981.

Watts, R. G., Global climate variations due to fluctuations in the rate of deep water formation, J. Geophys. Res., 90 (D5), 8067-8070, 1985.

Woillard, G., Grande Pile peat bog: A continuous pollen record for the last 140,000 years, Quat. Res., 9, 1-21, 1978.

E. Bard, Laboratoire de Geosciences de l'Environnement, Univèrsite d' Aix-Marseille III, Facultè de St Jèrôme, 13397 Marseille cedex 13, France.

J. C. Duplessy and L. Labeyrie, Centre des Faibles Radioactivitès, Laboratoire mixte CNRS-CEA, Parc du CNRS, 91198 Gif sur Yvette cedex, France.

J. Duprat and J. Moyes, Laboratoire de Gèologie et Ocèanographie, Universitè de Bordeaux-1, 33405 Talence, France.

(Received March 18, 1992; revised February 23, 1993; accepted February 23, 1993.) 